
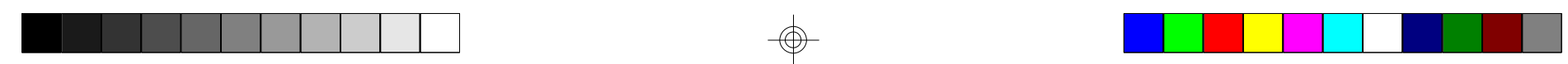

GEOUSP - Espaço e Tempo, São Paulo, No 20, pp. 189 - 191, 2006

\title{
BREVES NOTAS SOBRE O VIII COLÓQUIO DE GEOCRÍTICA
}

\author{
José Aldemir de Oliveira*
}

Foi realizado no final de maio, na cidade do México, o VII Colóquio Internacional de Geocrítica, evento que tem acontecido anualmente em diferentes países iberoamericanos e encerrará o primeiro ciclo com o X Colóquio Internacional em 2008 na cidade de Barcelona, onde ocorreu o primeiro em 1999.

O Colóquio reuniu pesquisadores especialmente ibero-americanos que apresentaram resultados de pesquisas envolvendo questões atuais da geografia. O tema, neste VIII - "Geografia Histórica e História do Território" -, conforme apontou o coordenador do evento, Horácio Capel, na conferência de abertura, visa lançar um olhar sobre o passado para corrigir os erros do presente e apontar os caminhos do futuro, possibilitando a correção das injustiças sociais, construindo uma análise crítica acerca de suas causas. Nesse contexto, o Colóquio busca reforçar os compromissos dos geógrafos com os graves problemas sociais que se concretizam em desigualdades espaciais e na forma pela qual os diferentes sujeitos se apropriam do território, construindo um futuro que respeite as tradições.

As palavras do coordenador do Colóquio ressaltaram ainda a perspectiva de romper com o processo em curso no nosso agora marcado pelo entendimento dos lugares como se fossem iguais, numa tendência de produção de formas espaciais desligadas da história e da cultura do lugar, tornando os homens e as mulheres reféns da lógica de um mundo distante, das possibilidades ilimitadas, na ilusão de que se podem reinventar formas espaciais iguais em qualquer lugar para projetar um mundo que unifique o ambiente simbólico e atenda interesses determinados, substituindo, conseqüentemente, a especificidade da cultura e da história de cada lugar.

Por fim, Capel apontou que as mudanças não apresentam o mesmo ritmo: algumas formas do passado permanecem e outras se transformam. Em decorrência, pode-se acrescentar que o resgate de modos pretéritos de produção de formas espaciais chega quase sempre a nós sem as vozes dos simples e dos conflitos que são abafados. Todavia, as especificidades dos lugares explicitam as contradições e os modos diferenciados de os sujeitos sociais se relacionarem com o seu espaço. Neste sentido, a espacialização que se vai construindo com permanências e transformações corresponde às reações coletivas e aos conflitos que passam pela cultura e pela memória, ou seja, por ações concretas dos vários sujeitos sociais que constituem a resistência coletiva à tendência homogeneizante que se lhes impõe.

Cabe indagar: os trabalhos apresentados no VIII Colóquio correspondem a essa expectativa? Dada a variedade e riqueza de temas abordados, a resposta é sim e não. Sim, do ponto de vista da temporalidade dos trabalhos que abarcam questões da pré-história,

*Professor do Programa de Pós-Graduação Sociedade e Cultura na Amazônia - UFAM; participou do evento acima referido com o apoio do PROAP-CAPES. E-mail: j-aldemir@uol.com.br 
passando pela colonização das Américas a temas atuais ligados à globalização, cujas análises quase sempre estão ligadas ao patrimônio material e imaterial. Não, porque alguns trabalhos trataram o espaço como algo em si mesmo, como se fosse possível interpretá-lo e compreendê-lo dissociado da sociedade que o produz, sem proceder à análise crítica dos processos, limitando-se ao tratamento dos dados sem apresentar questionamento da estrutura social da qual o espaço emerge. Emprestando a frase de uma participante do evento: "falta gente nestas pesquisas".

Outro destaque do Colóquio: a homenagem a um geógrafo pelo conjunto da obra, a quem foi concedido o Prêmio Internacional de Geocrítica. Outros importantes geógrafos já haviam sido homenageados: Elías Trabulse, Roberto Lobato Corrêa, Thomas F. Glick e Pedro Cunill. Neste VIII Colóquio o homenageado foi o geógrafo francês Robert Herin, que realiza trabalhos ligados à geografia agrária, tratando da migração, despovoamento e pobreza de áreas rurais da França e da Espanha. Herin, a partir dessa visão de Geografia, elabora juntamente com outros geógrafos na Université de Caen, o conceito de Geografia Social.

$\mathrm{Na}$ sua palestra, o Professor Robert Herin esclareceu que a Geografia Social consiste na explicação das inter-relações dos fatos sociais com o espaço para compreender as desigualdades, a mobilidade e as estruturas de poder, visando, com isso construir uma geografia preocupada com o tempo e com o espaço da vida. Segundo ele, a geografia deve ter compromisso com o rigor científico, mas esse rigor não deve ser neutro e por isso cabe ao geógrafo ter posições críticas e fazer de seu trabalho um contributo para a interpretação da realidade para além das aparências. Acrescentou ainda, que o trabalho do geógrafo deve ser pautado na ética, na crítica e na luta pela construção de um mundo melhor com igualdade de direitos, liberdade e fraternidade.
Bem ao estilo da geografia crítica, Robert Herin, destacou em seu discurso, que, ao mesmo tempo em que é necessário compreender a realidade com rigor científico, deve-se ficar comprometido para desvendar as velhas e as novas máscaras sociais que se concretizam no espaço. O discurso de Robert Herin pareceu-me bem mais apaixonante do que o texto já publicado, juntamente com os demais apresentados no VIII Colóquio, na Revista Scripta Nova. Revista electrónica de geografía y ciencias sociales, da Universidad de Barcelona, volume $X$ de agosto de 2006, disponível no site http://www.ub.es/geocrit/sn/sn-21835.htm.

Outro aspecto importante do Colóquio refere-se ao local de sua realização - a Cidade do México. Uma cidade que vai do urbanismo caótico à invenção da beleza. Uma cidade que afirma a sua altivez no desejo de construir em direção ao céu na verticalidade expressa pelas torres. De modo contraditório, a cidade criou a beleza artística urbana de suas igrejas e construções antigas e a feiúra dos subterrâneos e de um trânsito em que parece não haver lugar para nenhuma lógica. O centro histórico que não se pode atá-lo apenas ao pedestal de um patrimônio, como museu, mas como múltiplos centros de comércio popular, de manifestações políticas e de gente, muita gente. O centro torna-se nevrálgico e a cidade parece caminhar na direção do policentrismo, cuja funcionalidade só é obtida se articulada à circulação. Por outro lado, se o centro perde energia, ganha em prestígio. É que o centro permite, num relance, ver a cidade pretérita, combinar as formas e conteúdos do passado. A cidade cresce em todas as direções, mas o centro sobreviverá, pela busca do reencontro do homem consigo e com o seu passado. Se na cidade antiga havia beleza e a dimensão da obra, a cidade contemporânea está prestes a conceber novos encantos em todos os cantos. 


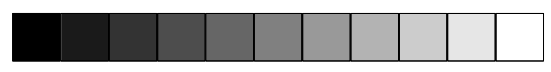

Notícias de Encontro: Breves notas sobre o VIII Colóquio de Geocrítica, pp. 189 - 191

Por fim, destaque-se o número de brasileiros participantes do Colóquio, o que mostra dois aspectos: O primeiro, a pujança da Geografia Brasileira com a ampliação de grupos de pesquisa e a criação de novos cursos de pós-graduação. O segundo, algo que parece tabu e por isso fingimos não reconhecer, que é o papel desempenhado pelas agências de fomento à pesquisa do sistema federal e agências estaduais, as FAPs. Com certeza, poucos brasileiros que participaram do colóquio o fizeram às suas expensas, mas com recursos de projetos de pesquisas. Isso é muito positivo, pois se trata de uma conquista dos pesquisadores brasileiros.

Por tudo isso, o saldo do Colóquio é positivo por estar atendendo a um projeto político no sentido de aprofundar os laços entre pesquisadores dos países iberoamericanos e contribuir para a criação de uma agenda científica para essa parte do mundo. Projeto científico concebido sempre como coletivo e integrador, visando explorar novas interpretações sobre a sociedade e o espaço. Para tanto, busca estabelecer laços e redes, fomentando o debate e difundindo novas idéias capazes de pôr em xeque as verdades arraigadas. Para isso, o IX Colóquio já está marcado para maio e junho de 2007, na cidade de Porto Alegre no Brasil, com o tema: "Los problemas del mundo actual soluciones y alternativas desde la geografia e las ciencias sociales". Estejamos lá para uma análise crítica da geocrítica e confiando no encontro de pessoas que acreditam na ciência no geral e na geografia em particular como contribuição para a construção de um mundo melhor.

Enviado em agosto de 2006.

Aceito em setembro de 2006. 